\title{
Epstein-barr virus may not be associated with breast cancer in Iranian patients
}

\author{
Pedram Fadavi ${ }^{1}$, Mosayeb Rostamian ${ }^{2}$, Arash Arashkia ${ }^{3}$, Behrooz Shafaghi ${ }^{4}$ and Hamid Mahmoudzadeh Niknam ${ }^{2 *}$ \\ *Correspondence: mahmoudzadehh@yahoo.com \\ ${ }^{1}$ Radiation Oncology Department, Faculty of Medicine, Iran University of Medical Sciences, Tehran, Iran. \\ 2Immunology Department, Pasteur Institute of Iran, Tehran, Iran. \\ ${ }^{3}$ Virology Department, Pasteur Institute of Iran, Tehran, Iran. \\ ${ }^{4}$ Pathology Department, Faculty of Medicine, Shahid Beheshti University of Medical Sciences, Tehran, Iran.
}

\begin{abstract}
Background: Epstein-Barr Virus (EBV) is a human herpes virus which infects over $90 \%$ of the world's population. This virus has been implicated in the pathogenesis of many types of cancers. Breast cancer is the most common cancer among women worldwide. EBV has been studied as a possible cause of human breast cancer. The data related to the possible association of EBV with breast cancer are contradictory and therefore inconclusive. Here we searched for EBV in Iranian patients with breast cancer.

Methods: Paraffin embedded formalin fixed specimens were prepared from malignant tumor tissue from eighteen Iranian patients with clinically proven breast cancer. EBV as well as human cells were detected and quantified by PCR and real-time PCR, respectively. The ratio of EBV/human cells was calculated in specimens from all patients.

Results: EBV was not detected in any of breast cancer tissues in our study. Quantitative analysis showed that EBV is not present in any specimens at level of one virus per each human cell.

Conclusion: Our results showed that EBV may not be associated with breast cancer in our patients suggesting that EBV might not have a significant role in this disease in Iran.
\end{abstract}

Keywords: Epstein-Barr virus, breast cancer, paraffin embedding, real-time polymerase chain reaction

\section{Introduction}

Epstein-Barr Virus (EBV) is a human herpes virus which infects over $90 \%$ of the world's population in the childhood and remains in the body for life [1]. Although most humans live with the virus without overt disease, a small proportion will develop tumors. EBV was the first human virus clearly involved in development of human cancer [2]. EBV is important in the pathogenesis of many cancers such as Burkitt's lymphoma and nasopharyngeal carcinoma [2]. The cancers associated with EBV vary markedly in viral prevalence, from $100 \%$ of nasopharyngeal carcinoma to about $10 \%$ of gastric carcinoma $[3,4]$. Although EBV infection is important in carcinogenesis, it is not sufficient and other risk factors such as epidemiological ones may play an additional critical role in cancer development [5]. Normal host populations can have large differences in susceptibility to EBV-related tumors and this may be shown by differences in geographical prevalence and different immunological presentation of these cancers [2]. In cancers for which epidemiologic and molecular virological data support a causal link with EBV, majority of tumor cells present DNA and other products of this virus [1].

Breast cancer is the most common cancer among women worldwide [6]. The etiology of breast cancer is not completely understood and the known breast cancer risk factors explain only a small fraction of this disease [7].
Epstein-Barr Virus (EBV) has been studied as possible cause of human breast cancer. However, the published data remain preliminary, and do not justify a conclusion that EBV is causally associated with breast cancer [8]. The proportion of EBV-positive malignant samples ranged from $0 \%$ to $100 \%$ [8]. A recent meta-analysis failed to resolve this controversy, although suggested a significant association between EBV infection and breast cancer [9].

The available data regarding the possible association of EBV with breast cancer are not concordant and therefore inconclusive. These contradictions may originate from different sensitivities of the assay used, and various definitions of "EBV positive" [10]. Differences in sample types (paraffin-embedded tissue or fresh tissues) and different populations studied (Asian, European, American, etc.) may contribute to these discrepancies [9].

Some authors defined "EBV positive" to mean that the majority of tumor cells each have at least one copy of EBV DNA [10]. This definition seems to be valid because it is true for all human tumors with established EBV associations [10].

The first step for showing the association of a cancer with a virus is to demonstrate the virus in the affected tissue [8]. Molecular techniques are the most definitive assays in establishing viral presence in comparison to other tests based on host antibody assessment and immunohistochemistry 
Fadavi et al. Oncology Discovery 2013,

http://www.hoajonline.com/journals/pdf/2052-6199-1-3.pdf

doi: $10.7243 / 2052-6199-1-3$

Table 1. Histopathologic data and EBV per cell for Iranian breast cancer patients studied.

\begin{tabular}{|c|c|c|c|c|c|c|c|c|c|}
\hline Patients No. & Age & Diagnosis & Grade & Size $(\mathbf{c m})$ & ER & PR & LNM & $\begin{array}{c}\text { Human cell/ } \mu \text { l extracted } \\
\text { DNA }\end{array}$ & EBV copy/Cell \\
\hline 1 & 41 & IDC & 3 & 3.5 & NA & NA & + & $8,635.99$ & $<0.029$ \\
\hline 2 & 40 & IDC & 2 & 2.5 & NA & NA & + & $6,556.02$ & $<0.038$ \\
\hline 3 & 55 & IDC & 2 & 2.3 & NA & NA & - & $4,649.64$ & $<0.054$ \\
\hline 4 & 65 & IDC & 3 & 4 & + & - & + & $6,895.11$ & $<0.036$ \\
\hline 5 & 64 & ILC & NA & 2.5 & + & + & - & $6,278.75$ & $<0.040$ \\
\hline 6 & 65 & IDC & 3 & 2.5 & + & + & + & $4,170.07$ & $<0.060$ \\
\hline 7 & 53 & IDC & 1 & 1.5 & + & + & - & $2,215.78$ & $<0.113$ \\
\hline 8 & 54 & IDC & 2 & 2 & + & + & NA & $3,140.43$ & $<0.080$ \\
\hline 9 & 51 & IDC & 2 & 1.8 & + & + & + & 660.60 & $<0.378$ \\
\hline 10 & 66 & IDC & 2 & 1.6 & + & + & - & 861.78 & $<0.290$ \\
\hline 11 & 62 & IDC & 2 & 3 & + & + & + & $4,456.13$ & $<0.056$ \\
\hline 12 & 46 & IDC & 2 & 1.5 & + & + & + & 250.91 & $<0.996$ \\
\hline 13 & 48 & IDC & NA & 3.5 & NA & NA & + & 452.90 & $<0.552$ \\
\hline 14 & 32 & ILC & NA & 3.5 & + & + & + & $1,187.51$ & $<0.210$ \\
\hline 15 & 58 & IDC & 2 & 1.5 & + & + & - & $1,902.21$ & $<0.131$ \\
\hline 16 & 41 & IDC & 3 & NA & NA & NA & + & $2,630.46$ & $<0.095$ \\
\hline 17 & 44 & IDC & 3 & 3 & NA & NA & + & $1,148.71$ & $<0.218$ \\
\hline 18 & 52 & IDC & 2 & 2 & + & + & + & 824.36 & $<0.303$ \\
\hline Raji cell & -- & -- & - - & -- & -- & -- & -- & $3,989.83$ & 65.09 \\
\hline
\end{tabular}

Abbreviations: IDC, infiltrating ductal carcinoma; ILC, infiltrating lobular carcinoma; ER, estrogen receptor; PR, progesterone receptor; LNM, lymph node metastasis; NA, not assayed.

[8]. Up to now, no standard method has been generally accepted for EBV detection in cancer tissues [11]. PCR and Real-Time PCR have been considered as the most sensitive methods and have been used frequently to detect EBV $[10,12-16]$. It is necessary to measure viral load by real-time PCR and report the ratio of viral load to an endogenous gene so as to adjust for the quantity and quality of DNA extraction in the sample [5]. Here we determined the numbers of EBV as well as the human cells in paraffin-embedded malignant tissues in Iranian patients with breast cancer for finding the relationship between EBV and breast cancer.

\section{Materials and methods Patients and samples}

Eighteen patients with clinically proven breast cancer were selected from Pars General Hospital in Tehran, Iran. Biological characteristics of these patients are shown in Table 1. Paraffin embedded formalin fixed specimen were prepared from malignant tumor tissue of each patient. DNA was extracted from malignant tissue within 3-7 days of their collection from patients.

\section{DNA extraction}

Three sections ( $8 \mu \mathrm{m}$ thickness each) were prepared from paraffin embedded formalin fixed malignant tissue of each patient. DNA extraction was performed by QIAamp ${ }^{\oplus}$ DNA
FFPE Tissue Kit (Qiagen, Hilden, Germany). The DNA extraction method was mainly according to procedure provided by the company with few modifications as follows: sections were placed in a $1.5 \mathrm{ml}$ centrifuge tubes, $1 \mathrm{ml}$ xylene (Merck, Darmstadt, Germany) was added immediately and centrifuged $\left(16000 \times \mathrm{g}, 2 \mathrm{~min}, 25^{\circ} \mathrm{C}\right)$ to remove paraffin. The supernatant was discarded and the pellet was resuspended in $1 \mathrm{ml}$ pure ethanol (Merck, Darmstadt, Germany) and centrifuged for 2 min, $16000 \times \mathrm{g}$ at $25^{\circ} \mathrm{C}$. The supernatant was discarded; the pellet was resuspended in $180 \mu \mathrm{l}$ ATL buffer (QIAamp ${ }^{\circledR}$ DNA FFPE Tissue Kit) and $20 \mu$ l proteinase K (Vivantis, Malaysia), and incubated at $56^{\circ} \mathrm{C}$ overnight. DNA was eluted in $50 \mu \mathrm{l}$ ATE buffer (QIAamp ${ }^{\circledR}$ DNA FFPE Tissue Kit) and stored at $-70^{\circ} \mathrm{C}$ until use.

\section{Raji cell}

Raji cell line, as EBV-positive control, was purchased from Cell Bank of Pasteur Institute of Iran, cultured in RPMI 1640 supplemented with $10 \% \mathrm{FBS}, 2 \mathrm{mM}$ L-glutamine (SIGMA, USA), Penicillin (100 lU/ml) and Streptomycin $(100 \mu \mathrm{g} / \mathrm{ml})$. Cells were cultured at starting concentration of $10^{5} \mathrm{cell} /$ $\mathrm{ml}$ and were subcultured at concentration of $2 \times 10^{6} \mathrm{cell} /$ $\mathrm{ml}$ at about 3-day intervals. The cells were counted using Neubauer Chamber hemocytometer (Marienfeld, Harsewinkel, Germany) and aliquots of $2 \times 10^{5}$ cells were prepared in $0.2 \mathrm{ml}$ centrifuge tubes by centrifugation $\left(400 \times \mathrm{g}, 6 \mathrm{~min}\right.$, at $\left.25^{\circ} \mathrm{C}\right)$. Finally the supernatants were discarded and pellets were 


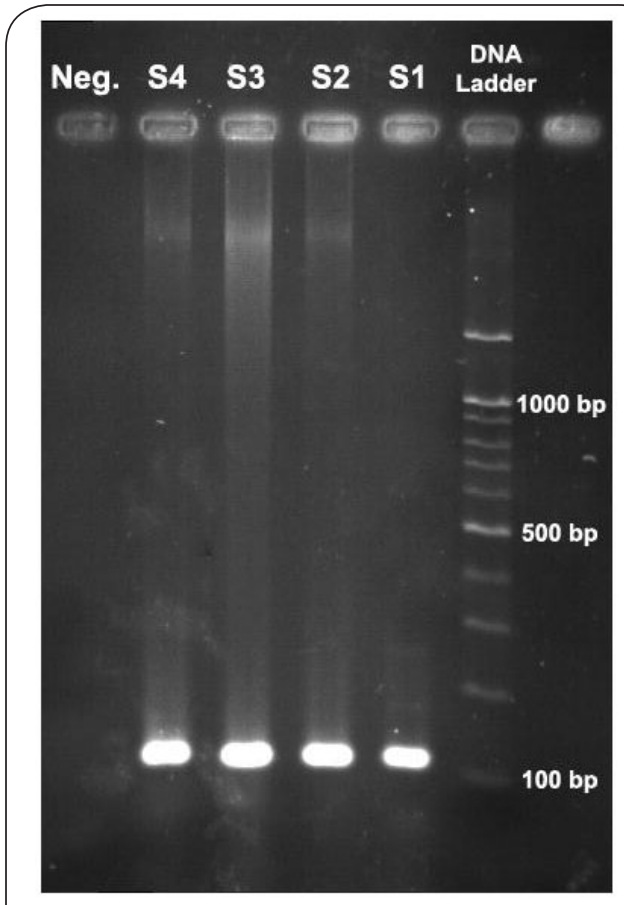

Figure 1. Quality of the extracted DNA from specimens was acceptable for PCR because beta-Globin was successfully amplified from the extracted DNA.

Sharp single bands ( $110 \mathrm{bp}$ ) corresponding to beta-Globin are observed in the lanes of the samples (S1 to S4), while no bands is seen in negative control lane (Neg.).

stored at $-70^{\circ} \mathrm{C}$ until use. DNA extraction from aliquots of Raji cell was performed exactly as mentioned for tissue samples from patients using the same kit and procedure.

\section{PCR}

Amplification of BALF5 sequence of 90 base pairs by polymerase chain reaction (PCR) $[17,18]$ was used for detection of EBV. PCR was performed using following primers: forward: 5'-CGGAAGCCCTCTGGACTTC-3' and reverse: 5'-CCCTGTTTATCCGATGGAATG-3' $[17,18]$. BALF5 amplification contains $10 \mu \mathrm{l} 2$ X Taq DNA Poly Mix (Fermentas, Sankt LeonRot, Germany), $0.5 \mu \mathrm{M}$ of each primer, $2 \mu \mathrm{l}$ of extracted DNA, and distilled water up to $20 \mu \mathrm{l}$. The PCR program was $94^{\circ} \mathrm{C}$ for $5 \mathrm{~min}, 35 \mathrm{cycles}$ of $94^{\circ} \mathrm{C}$ for $30 \mathrm{sec}, 59^{\circ} \mathrm{C}$ for $30 \mathrm{sec}$, and $72^{\circ} \mathrm{C}$ for $45 \mathrm{sec}$. Final extension was $72^{\circ} \mathrm{C}$ for $5 \mathrm{~min}$. Suitability of DNA for PCR amplifications was assessed by amplifying the constitutive gene of beta-Globin. A 110- base pair fragment of beta-Globin gene was amplified using PCR by following primers: forward: 5'-ACACAACTGTGTTCACTAGC-3' and reverse: 5'-CAACTTCATCCACGTTCACC-3'. The reaction mixture for beta-Globin PCR was: $10 \mu \mathrm{l} \mathrm{PCR}$ Master Mix (Fermentas, Sankt Leon-Rot, Germany), $0.4 \mu \mathrm{M}$ of each primer, $2 \mu$ l of extracted DNA, and distilled water up to $20 \mu \mathrm{l}$. The PCR program for beta-Globin was: $95^{\circ} \mathrm{C}$ for $5 \mathrm{~min}, 35 \mathrm{cycles}$ of $95^{\circ} \mathrm{C}$ for $30 \mathrm{sec}$, $55^{\circ} \mathrm{C}$ for $30 \mathrm{sec}$, and $72^{\circ} \mathrm{C}$ for $30 \mathrm{sec}$, final extension $72^{\circ} \mathrm{C}$ for 7 min. No-template control, as a negative control, was included in all PCR runs as indicator of potential DNA contamination throughout the PCR process.

\section{Gel electrophoresis}

One microliter DNA sample buffer (Vivantis, Malaysia) was added to $5 \mu \mathrm{l}$ of PCR product of each sample, loaded on $2 \%$ agarose gel and electrophoresed with 120 volt for $40 \mathrm{~min}$. Green Viewer (Pars Tous, Iran) at $1 \%$ v/v was added to agarose gel to visualize the bands before loading of samples.

\section{Real-time PCR}

Real-time PCR was performed by using Corbett Rotor-Gene 6000 (QIAGEN, Valencia, USA). Real-time PCR amplifying of BALF5 was performed according to the method described for BALF5-PCR with some modifications: $5 \mu$ SYBR Green Master Mix (GenetBio, South Korea), $0.5 \mu \mathrm{M}$ of each primer, $1 \mu \mathrm{l}$ of extracted DNA, and $3 \mu$ l distilled water ( $10 \mu$ l final volume), 40 cycles of annealing was applied and the final extension was omitted. Different 2-fold serial dilutions of Raji cell DNA were used to prepare standard curve.

In order to calculate the ratio of EBV/human cell in specimens from each patient, the cell number of paraffinembedded tissues was determined. Beta-Globin gene was used for quantitation of cells in each sample. A 110 base pair sequence of beta-Globin gene was amplified by Real-Time $P C R$ with the same primers mentioned above for beta-GlobinPCR. The reaction mixture for beta-Globin Real-Time PCR was: $5 \mu \mathrm{l}$ SYBR Green Master Mix, $0.5 \mu \mathrm{M}$ of each primer, $1 \mu \mathrm{l}$ of extracted DNA, and $3 \mu \mathrm{l}$ distilled water (final volume of $10 \mu \mathrm{l}$ ). The amplification program for beta-Globin was same as mentioned above for beta-Globin-PCR except that 40 cycles of annealing was applied and the final extension was omitted. Standard curve was prepared by running three consecutive 5 fold dilutions of Raji DNA corresponding to 4000,800 , and 160 cells/ $\mu$ l of extracted DNA. Concentration of Raji cells were determined through counting by hemocytometer. Standard curve was drawn in each run, i.e., standards were run parallel to specimen in each assay.

Specificity of amplification for target sequences (betaGlobin and BALF5) were checked in real-time PCR through melt curve analysis and the results were accepted if non-specific amplification were not present. All samples and standards were assayed in duplicate in all Real-Time PCR tests, and the data were analyzed using Corbett Rotor-Gene 6000 software version 1.7.87.

\section{Results \\ Quality of the extracted DNA}

Beta-Globin is a constitutive gene in human genome, so PCR amplification of beta-Globin shows acceptable quality of the extracted human DNA as far as PCR is concerned. As shown in Figure 1, PCR amplification of DNA extracted from 
Fadavi et al. Oncology Discovery 2013,

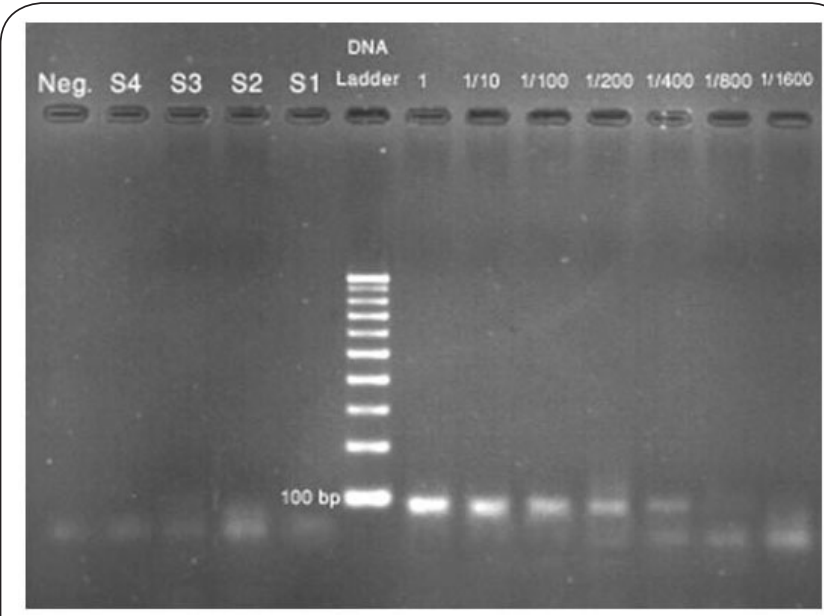

Figure 2. PCR amplification of EBV BALF5 sequence. Serial dilutions of Raji DNA (1-1/1600) were applied to find the lowest number of EBV (i.e., BALF5 sequence) copy that can be detected by PCR. The right panel shows that up to $1 / 400$ dilution of Raji DNA (which is equal to 500 copies of EBV) can be detected in our PCR setting. In the left panel, PCR amplification of BALF5 sequence was performed to find EBV in DNA extracted from tumor specimens (S1, S2, S3, and S4). No band was observed in any tumor specimens suggesting that no EBV genome is detectable in the specimens.

Abbreviations: S1 - S4: sample 1 - sample 4; Neg.: negative control.

patients tumor tissues resulted in a sharp single band of 110 base pair compatible with beta-Globin. These data indicated that the DNA extracted from paraffin embedded formalin fixed specimen had acceptable quality for PCR.

\section{Sensitivity of the EBV detection}

Raji cell line contains $~ 50$ EBV copies/cell [19]. Each EBV virus contains one BALF copy $[\mathbf{2 0 , 2 1 ]}$. In order to determine the sensitivity of our BALF5-PCR and Real-Time PCR assay, the extracted DNA from $2 \times 10^{5}$ Raji cells (eluted in $50 \mu \mathrm{l}$ volume) was serially diluted, from undiluted DNA (equal to $2 \times 10^{5}$ copy of BALF $5 / \mu$ l of extracted DNA) to dilution of $1 / 1600$ (equal to 125 copy of BALF5/ $\mu$ l of extracted DNA), and used as templates in BALF5-PCR as well as in Real-Time PCR assays. Serial dilutions of Raji genome were applied to find the lowest copy number of EBV (i.e., BALF5 sequence) that can be detected by PCR and Real-Time PCR.

The result of BALF5-PCR (Figure 2) showed that the lowest level of detection in our BALF5-PCR assay is about 10 Raji genome/ $\mu$ l of extracted DNA (equivalent to 500 copies of BALF5 sequence/ $\mu$ l of extracted DNA). This assumption is based on the following calculation: DNA of $2 \times 10^{5}$ Raji cells were extracted in $50 \mu \mathrm{l}$ volume, $2 \mu \mathrm{l}$ of the extracted DNA was used in $20 \mu \mathrm{l}-\mathrm{PCR}$ mix, and $5 \mu \mathrm{l}$ of this reaction mix was loaded in each well during electrophoresis $\left(2 \times 10^{5}\right.$ Raji cells DNA / $50 \mu \mathrm{l} \times 2 \mu \mathrm{l} / 20 \mu \mathrm{l} \times 5 \mu \mathrm{l} /$ dilution of $400=5$ Raji cells/
$2 \mu$ l of extracted DNA which equals to 10 Raji cell or 500 BALF5 sequence/ $\mu$ l of extracted DNA).

The result of Real-time PCR for BALF5 showed that about 250 copies of BALF5 sequence can be detected in each microliter of extracted DNA. This result is calculated as follows: $2 \times 10^{5}$ Raji cells DNA / $50 \mu \mathrm{l} /$ dilution of $800=5$ Raji cells or 250 EBV copies.

We measured the number of human cells in each patient's specimen in order to calculate EBV/human cell ratio in each patient. Numbers of human cell were determined by quantifying beta-Globin copy number in each specimen. Beta-Globin was amplified by real-time PCR in consecutive 5 fold serial dilutions of Raji cells with defined cell numbers. Concentration of Raji cells were determined through counting by hemocytometer. A standard curve was drawn by plotting cell numbers in one axis versus $\mathrm{Ct}$ values of amplified beta-Globin sequence on the other axis. Hence the relationship between numbers of human cell and copy numbers of beta-Globin were obtained. The standard curve ( $\mathrm{R}^{2}: 0.99$ and Efficiency: 1.01) was used for calculation of human cell numbers in each patient's specimen. The numbers of human cells in each specimen are presented in Table 1. Specimens contained 250 to 8635 (mean 2302) human cells/ $\mu$ l of extracted DNA.

\section{No EBV was detected in all specimens}

Since BALF5 is a non-repetitive and constitutive sequence in EBV genome [20,21], presence of this sequence was studied by PCR and its copy number was determined by real-time $P C R$ in patient's specimen. The PCR were negative for all the patients' specimens (Figure 2) showing that there is no EBV genome detectable in any of them. The results of Real-Time PCR confirmed the PCR results, i.e., all the specimen were negative.

\section{$\mathrm{EBV} / \mathrm{human}$ cell ratio}

Beta-Globin copy numbers were determined in specimens from all the breast cancer patients (Table 1) in order to calculate the number of human cells of each specimen. The ratio of EBV virus to human cells was then calculated for every specimen. The number of human cells of each specimen was about 250 to 8600 . The ratio of EBV/human cells was between $<0.03$ to $<0.99$ in all the specimens studied.

\section{Discussion}

Choosing a reliable method is a critical step in EBV detection studies. PCR and Real-Time PCR are considered as sensitive methods and have been used frequently in EBV detection $[10,12-16,22-24]$, so we used these techniques to detect the virus in tumor tissues. Beta-Globin is a constitutive gene present in human DNA, so amplifying beta-Globin with PCR can be used for assessing the quality and quantity of the extracted DNA. Therefore we applied beta-Globin PCR for all specimens and confirmed that the extracted DNA had acceptable quality and quantity for amplification through PCR. 
On the other hand, formalin which is used for preparation of formalin-fixed paraffin-embedded tissues may fragmentize the DNA and interfere with PCR amplification of large sequence of DNA templates. A simple way for reducing the effect of DNA degradation on the EBV detection in specimens is targeting of short DNA sequences ( $<200$ base pair) in PCR [25]. Thus here we amplified a 90 base pair sequence (BALF5) of EBV genome, encoding EBV DNA polymerase $[20,21]$ for EBV detection in tissue specimens.

A previous study reported no association between EBV and breast cancer in Iranian patients [26]. However this study suffers from major shortcomings. Firstly, no EBV-positive control specimen is included in the study, thus their negative results may be due to many variables including unsuitable PCR condition. Secondly, sensitivity of the EBV detection assay was not defined in the study. So it is not clear that how many EBV viruses were left un-detected in the study. Hence the reported negative results cannot be compared with other reports. Therefore in the present study we used Raji cell line as an EBV-positive control to eliminate false negative results and also to define sensitivity of our assays.

Our results showed that all the 18 patients in our study did not have any detectable EBV in real time PCR. The ratios of EBV/human cells were determined in specimens from all breast cancer patients in our study in order to compare our data with those of other reports. The ratio of EBV/human cells in all the breast cancer patients were below one EBV per each human cell. This ratio is much lower than the ratio of EBV/human cells in Raji cell (about 50), which is a Burkit lymphoma cell [19]. Hence all the breast cancer tissue samples were negative in comparison to a well defined EBV positive cancer cell. The definition of one or more EBV per each human cell is considered to be true for all human cancers for which EBV was associated with the malignancy definitely [10]. Considering this definition, all the breast cancer tissues of our study were negative, because the ratio of EBV/human cell was less than 1 in all patients.

EBV was not detected in any of specimen in our study. On the other hand, it is well known that EBV infects most of humans and remains in the body for life. No EBV was detected in any specimens in our study. This finding may be explained by the low sensitivity of our EBV detection assay. Our assay was able to detect only the high EBV load present in pathological cases like Raji cell and not the low EBV load present in most of humans. Our assay will become positive if there is at least 250-500 copy of EBV/ $\mu$ l of extracted DNA. Therefore this assay has not been sufficiently sensitive to detect the low copy number of EBV present in most humans. This assumption is based on the following calculation: the frequency of EBV infected cells in infected individuals is about 1 infected cell for every $10^{4} \mathrm{~B}$ cells [27]. Our specimen contain maximum of 8635 human cells/ $\mu$ of extracted DNA and $B$ cells may be a small fraction of these cells. Assuming that all cells in our specimen are B cell, about $0.86(\approx 1)$ EBV infected cell should have been present in the specimen containing the highest numbers of cells $(8635 / 10000=0.86)$. Assuming that the copy number of EBV in each B cell and Raji cell (as a definite EBV positive control) are equal, there should have been about $43(0.86 \times 50=43) \mathrm{EBV}$ copy/ $/ \mathrm{l}$ of the extracted DNA from our specimen containing highest human cells. The 43 copy is lower than the detection limit of $250 \mathrm{EBV} / \mu \mathrm{l}$ of extracted DNA in our assay. In other words the low level of EBV present in most of humans is not detected in our assay, while the assay can detect higher levels of EBV that are present in pathologic "EBV positive" cells like Raji cell. We did not study women with no history of breast cancer as controls because no pathological levels of EBV were found in malignant specimens.

In summary, our results showed that no pathological levels of EBV were detected in breast caner tissues of Iranian patients we examined, suggesting that EBV may not have a significant role or at least is uncommon in this disease in Iran. Similar suggestion has also been reported $[10,28]$. It should be also noted that finding the definite relationship between EBV and breast cancer in Iranian patients needs further studies on an increased number of patients.

\section{Competing interests}

The authors declare that they have no competing interests.

Authors' contributions

$\mathrm{HM}$ and PF conceived idea of the research. HM, PF, BS, $M R$, and AA developed design of the research. PF and BS provided the patients' specimens and their clinical and pathological data. HM and MR performed the experiments. All authors have read and corrected the manuscript.

Acknowledgement

Kind helps of authorities of pathology lab of Pars General Hospital, especially Dr. Roya Hajmohammadi are appreciated.

\section{Publication history}

Editor: Scaggiante Bruna, University of Trieste, Italy. EIC: Paul J. Higgins, Albany Medical College, USA. Received: 10-Apr-2013 Revised: 13-May-2013 Re-Revised: 22-Jun-2013 Accepted: 15-Jul-2013 Published: 29-Jul-2013

\section{References}

1. Crawford DH. Biology and disease associations of Epstein-Barr virus. Philos Trans R Soc Lond B Biol Sci. 2001; 356:461-73. | Article I PubMed Abstract | PubMed Full Text

2. Thompson MP and Kurzrock R. Epstein-Barr virus and cancer. Clin Cancer Res. 2004; 10:803-21. | Article I PubMed

3. Gulley ML. Molecular diagnosis of Epstein-Barr virus-related diseases. J Mol Diagn. 2001; 3:1-10. | Article | PubMed Abstract | PubMed Full Text

4. Hsu JL and Glaser SL. Epstein-barr virus-associated malignancies: epidemiologic patterns and etiologic implications. Crit Rev Oncol Hematol. 2000; 34:27-53. | Article | PubMed

5. Glaser SL, Hsu JL and Gulley ML. Epstein-Barr virus and breast cancer: state of the evidence for viral carcinogenesis. Cancer Epidemiol Biomarkers Prev. 2004; 13:688-97. I Article I PubMed

6. WHO: The global burden of disease, 2004 update. 2008. | Website 
Fadavi et al. Oncology Discovery 2013,

7. Dumitrescu RG and Cotarla I. Understanding breast cancer risk -- where do we stand in 2005? J Cell Mol Med. 2005; 9:208-21. | Article | PubMed

8. Joshi $D$ and Buehring GC. Are viruses associated with human breast cancer? Scrutinizing the molecular evidence. Breast Cancer Res Treat. 2012; 135:1-15. | Article | PubMed

9. Huo $Q$, Zhang $N$ and Yang $Q$. Epstein-Barr virus infection and sporadic breast cancer risk: a meta-analysis. PLoS One. 2012; 7:e31656. | Article | PubMed Abstract | PubMed Full Text

10. Perrigoue JG, den Boon JA, Friedl A, Newton MA, Ahlquist P and Sugden B. Lack of association between EBV and breast carcinoma. Cancer Epidemiol Biomarkers Prev. 2005; 14:809-14. | Article | PubMed

11. He JR, Song EW and Ren ZF. Research advancement on relationship between Epstein-Barr virus and breast cancer. Ai Zheng. 2009; 28:82730. | PubMed

12. Saito I, Servenius B, Compton T and Fox RI. Detection of Epstein-Barr virus DNA by polymerase chain reaction in blood and tissue biopsies from patients with Sjogren's syndrome. J Exp Med. 1989; 169:2191-8. | Article | PubMed Abstract | PubMed Full Text

13. Telenti A, Marshall WF and Smith TF. Detection of Epstein-Barr virus by polymerase chain reaction. J Clin Microbiol. 1990; 28:2187-90. | Article | PubMed Abstract | PubMed Full Text

14. Wagner HJ, Bein G, Bitsch A and Kirchner H. Detection and quantification of latently infected B lymphocytes in Epstein-Barr virus-seropositive, healthy individuals by polymerase chain reaction. J Clin Microbiol. 1992; 30:2826-9. | Article | PubMed Abstract | PubMed Full Text

15. Lee MA, Hong YS, Kang JH, Lee KS, You JY, Lee KY and Park CH. Detection of Epstein-Barr virus by PCR and expression of LMP1, p53, CD44 in gastric cancer. Korean J Intern Med. 2004; 19:43-7. | Article | PubMed

16. Arbach H, Viglasky V, Lefeu F, Guinebretiere JM, Ramirez V, Bride N, Boualaga N, Bauchet T, Peyrat JP, Mathieu MC, Mourah S, Podgorniak MP, Seignerin JM, Takada K and Joab I. Epstein-Barr virus (EBV) genome and expression in breast cancer tissue: effect of EBV infection of breast cancer cells on resistance to paclitaxel (Taxol). J Virol. 2006; 80:845-53. Article | PubMed Abstract | PubMed Full Text

17. Kimura H, Morita M, Yabuta Y, Kuzushima K, Kato K, Kojima S, Matsuyama T and Morishima T. Quantitative analysis of Epstein-Barr virus load by using a real-time PCR assay. J Clin Microbiol. 1999; 37:132-6. | Article | PubMed Abstract | PubMed Full Text

18. Wadowsky RM, Laus S, Green M, Webber SA and Rowe D. Measurement of Epstein-Barr virus DNA loads in whole blood and plasma by TaqMan PCR and in peripheral blood lymphocytes by competitive PCR. J Clin Microbiol. 2003; 41:5245-9. | Article | PubMed Abstract | PubMed Full Text

19. Sternas L, Middleton T and Sugden B. The average number of molecules of Epstein-Barr nuclear antigen 1 per cell does not correlate with the average number of Epstein-Barr virus (EBV) DNA molecules per cell among different clones of EBV-immortalized cells. J Virol. 1990; 64:2407-10. | Article | PubMed Abstract | PubMed Full Text

20. Baer R, Bankier AT, Biggin MD, Deininger PL, Farrell PJ, Gibson TJ, Hatfull G, Hudson GS, Satchwell SC, Seguin C and et al. DNA sequence and expression of the B95-8 Epstein-Barr virus genome. Nature. 1984; 310:207-11. | Article | PubMed

21. Dolan A, Addison C, Gatherer D, Davison AJ and McGeoch DJ. The genome of Epstein-Barr virus type 2 strain AG876. Virology. 2006; 350:164-70. | Article | PubMed

22. Riddler SA, Breinig MC and McKnight JL. Increased levels of circulating Epstein-Barr virus (EBV)-infected lymphocytes and decreased EBV nuclear antigen antibody responses are associated with the development of posttransplant lymphoproliferative disease in solidorgan transplant recipients. Blood. 1994; 84:972-84. | Article | PubMed

23. Baldanti F, Grossi P, Furione M, Simoncini L, Sarasini A, Comoli P, Maccario R, Fiocchi R and Gerna G. High levels of Epstein-Barr virus DNA in blood of solid-organ transplant recipients and their value in predicting posttransplant lymphoproliferative disorders. J Clin Microbiol. 2000; 38:613-9. | Article | PubMed Abstract | PubMed Full $\underline{\text { Text }}$
24. Gustafsson A, Levitsky V, Zou JZ, Frisan T, Dalianis T, Ljungman P, Ringden $O$, Winiarski J, Ernberg I and Masucci MG. Epstein-Barr virus (EBV) load in bone marrow transplant recipients at risk to develop posttransplant lymphoproliferative disease: prophylactic infusion of EBV-specific cytotoxic T cells. Blood. 2000; 95:807-14. | Article | PubMed

25. Gillio-Tos A, De Marco L, Fiano V, Garcia-Bragado F, Dikshit R, Boffetta $P$ and Merletti F. Efficient DNA extraction from 25-year-old paraffinembedded tissues: study of $\mathbf{3 6 5}$ samples. Pathology. 2007; 39:345-8. | Article I PubMed

26. Kadivar M, Monabati A, Joulaee A and Hosseini N. Epstein-Barr virus and breast cancer: lack of evidence for an association in Iranian women. Pathol Oncol Res. 2011; 17:489-92. | Article | PubMed

27. Miyashita EM, Yang B, Lam KM, Crawford DH and Thorley-Lawson DA. A novel form of Epstein-Barr virus latency in normal B cells in vivo. Cell. 1995; 80:593-601. | Article | PubMed

28. Hippocrate A, Oussaief $L$ and Joab I. Possible role of EBV in breast cancer and other unusually EBV-associated cancers. Cancer Lett. 2011; 305:1449. | Article | PubMed

\section{Citation:}

Fadavi P, Rostamian M, Arashkia A, Shafaghi B and Niknam HM. Epstein-barr virus may not be associated with breast cancer in Iranian patients. Oncol Discov. 2013; 1:3. http://dx.doi.org/10.7243/2052-6199-1-3 